\title{
Selection and Molecular Identification of Semi Dry Date Palm Seedlings Using RAPD Markers \\ Zeinab A.M. Abo-Rekab ${ }^{1}$; A.Y. El-Kerdany ${ }^{2}$; Ghada A. Ali ${ }^{2}$ and Y.M. Diab ${ }^{2}$ \\ ${ }^{1}$ Fruit and Ornamental Breeding Department, Horticulture Research Institute. \\ ${ }^{2}$ Central Lab of Date Palm Researches and Development, Agriculture Research Center.
}

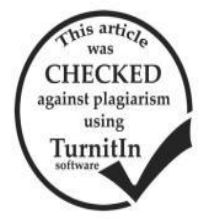

\section{ABSTRACT}

This investigation was carried out during two successive seasons $(2014-2015)$ at Fayoum governorate. The present investigation was divided into two parts. The first part aimed to select the high fruit quality of semi-dry maghal trees of date palm in Fayoum governorate. Panel taste evaluation, vegetative and morphological characters of trees, flowering, fruit set, fruit physical and chemical characteristics as well as mineral nutrients of fruitswere studied in six semi-dry maghal date palms compared to Seewy cultivar as control. The numerical selection of selected palms showed that date palm No. 6 recorded 96.38 units and gave the first rank, while tree No. 2 gave the sixth rank and gave 78.71 units and finally Seewy cultivar 70.43 units. Six semi-dry date palms were considered as an initial for a semi-dry date palm cultivars under Fayoum governorate. On the other hand, the second part aimed to characterize molecular genetic markers among the six semi-dry date palms and Seewy cultivar. Data of RAPD recorded a sum of 52 bands, where 29 bands among them were polymorphic bands and 23 bands were monomorphic in all trees under study. On the other hand, a strongest relationship was scored between tree No. 1 and tree No. 4 as well as between tree No. 6 and Seewy cultivar (similarity reached 100\%).

Keywords: Date palm, selection, semi-dry, panel taste, maghal, RAPD DNA.

\section{INTRODUCTION}

Date palm (Phoneixdactylifera L.) is one of the most fruit crop in Egypt. Egyptis one of the most productive countries of dates in the world. According to Annals of Agriculture Economics, A.R.E (2013) in Egypt, the number of fruitful female palms was about 2296593 producing about 1328468 tons date fruits. The nutritional value is rich in many minerals such as potassium, calcium, magnesium, phosphorus, sulfur and copper (Nixon and Carpenter, 1978). It was also rich in some vitamins such as vitamin $\mathrm{C}, \mathrm{B} 2$, thiamine and nicotinic acid. Moreover, it contains high amounts of sugars ranged from 50 to $90 \%$ (El-Warrakiet al., 1989). Fayoum governorate is considered one of the main fresh and semi-dry date palm producer and have about 655270 palms producing 69474 tons. For successful improvement program of date palm, it could evaluate the unknown seedling palms already grown in the area. The selection of fruit trees is considered one of the important methods for improving fruit cultivars (Rokbaet al., 1990 and Abo-Rekab 2005 and 2013). The present investigation aimed to select the high fruit quality of unknown semi-dry date palm seedlings grown in different areas of Fayoum governorate, through studying both morphological and chemical characters of fruits. Correct identification of date palm trees is usually impossible until fruits are produced. In addition, the characterization of cultivars and evaluation of genetic diversity require a large set of phenotypic data which are often difficult to assess and sometimes varied due to environmental influences (Sedraet al., 1993 and 1998 and Abo-Rekab, 2013). Therefore, the second goal of this study is using randomly amplified polymorphic DNA (RAPD)as DNA fingerprinting for identification and calculating the genetic similarity among the studied semi-dry date palm trees.

\section{MATERIALS AND METHODS}

This investigation was carried out in two successive seasons (2014 and 2015). This study aimed to survey and selects the high fruit quality of semi-dry seedling trees of date palm seedlings grown in different areas of Fayoum governorate. The total number of surveyed date palm seedlings reached 50 seedling trees. The ages of the experimental palms were about 10 to 15 years old. First, panel taste was used as a survey tool for the determination of fruit quality of semi-dry date palm tested seedlings. According to the panel taste survey, only six trees were chosen for their best palm fruits qualities. The chosen six female date palm seedling trees were evaluated for vegetative characteristics of each palm tree. Three spathes were taken from each tree and evaluated for the physical and chemical characters of fruits. In addition, three female palms of Seewy cultivarswere included. The experimental palms were healthy, nearly uniform in grown, vigor, height and fruiting capacity in the preceding years. The trees were subjected to the normal cultural practices.

\section{1- Panel taste:}

For each studied seedlingpalm trees as well as for Seewy cultivar, a sample consisting of ten fruits for each tree were taken. The fruits were tagged and distributed each in a paper bag, a table chart containing the apparent fruit characteristics, i.e. colour, flavor, appearance, acceptability and mouth feel. The paper bag and the table chart were given to each panelist. It was requested from each panelist to translate his/her opinion about eating quality to a grade in the table sheet. The grade of fruits quality for each seedling was calculated as a mean from different types of panelist.

\section{2- Vegetative characteristics of date palm trees:}

In both seasons, vegetative characteristics of the six semi-dry seedling trees as well as for Seewy cultivar were measured at first week of October. Height, girth and trunk of each palm tree were measured in meters. The number of newly produced leaves per tree was counted. Leaf characteristics of each palm tree were measured on three full expanded leaves (leaf length, length of leaf base, number of leaflets per leaf, length of leaflet, number of spines per leaf, length of spine zone and length of spine time, dates of flowering, fruit setting and fruit harvesting were recorded for each studied palm 
tree. The average number and weight of bunch as well as the yield per palm tree were estimated.

\section{3-Fruit characteristics:}

Representative fruit sample (3 fruits) was collected at harvesting date (tamer stage). The fruit evaluation are included:

Fruit physical characters included the following parameters:the fruit weight $(\mathrm{g})$, flesh weight $(\mathrm{g})$, seed weight $(\mathrm{g})$. Fruit length $(\mathrm{cm})$ and fruit diameter $(\mathrm{cm})$ were measured by vainer caliper.

\section{Fruit chemical characters:}

\section{Moisture and dry matter content}

The flesh of fruits sampling was cut into small pieces and dried at $60-65{ }^{\circ} \mathrm{C}$ for $48 \mathrm{~h}$ until the constantweight (Dawson and Aten 1962), then the moisture and dry matter percentages were calculated.

\section{Total sugar determination}

Total sugars were determined colorimetrically at $490 \mathrm{~nm}$, using phenolsulphuric acid method (Dubois et $a l ., 1956)$ and calculated by means of the standard curve of glucose.

\section{Total soluble solids (TSS)}

Juice was used for determination of TSS percentage as $\mathrm{g} / 100 \mathrm{~g} \mathrm{FW}$ using hand refractometer according to the method described by Chen and Mellenthin (1981).

\section{Titratable acidity percentage}

Titratable acidity was determined in well mixed fruit juice $(5 \mathrm{ml})$ by titration against sodium hydroxide $(0.1 \mathrm{~N})$ using phenolphthalein as an indicator, as described by AOAC (1980). Acidity percentage was calculated as percentage of malic acid.

\section{Total phenols determination}

Total phenols concentration was determined colorimetricallyas the method described by Swain and Hillis (1959). Total phenols were calculated from the standard curve of Tannic acid. Phenols concentration was expressed as mg anhydrous floroglucinol/ 100g FW fruit peel.

\section{Tannins determination}

Total tannins concentration of date fruit peel was determined using the method described by Resenabatt and Peluso (1941). Tannins concentration was determined from standard curve of tannic acid. The tannic acid concentration was expressed as percentage.

\section{Total soluble indols determination}

Total soluble indols were determined in the ethanolic extract by using P-dimethyl amino benzaldehyde (Ehrlich's reagent, Larson et al., 1962). A stable pink color would be formed. Pure indol acetic acid was used as standard. Total indols were expressed on fruit dry weight basis as mg/ 100g DW.

\section{Crude fibers determination}

Determination of crude fibers was achieved by adding glacial acetic acid and nitric acid (10:1) on $1 \mathrm{~g}$ fruit flesh sample as described by AOAC (1985).

Total soluble free amino acids determination

Total soluble free amino acids were determined in the ethanolic extract by using the ninhydrin colorimetric method as the method described by Rosein (1957). Glutamic acid was used as standard. Total free amino acids concentration was expressed on fruit dry weight basis as mg/ 100g DW.

Total nitrogen and crude protein determination

Total nitrogen concentration was determined in dry material sample $(0.5 \mathrm{~g})$ by the modified microkjeldahl method as described by Pregl (1945). The protein concentration was calculated by multiplying the $\mathrm{N}$ value by the factor 6.25 .

\section{Mineral nutrients determinations}

A mixture containing concentrated nitric, perchloric and suphuric acid (3:2:1, v:v:v) was used for digestion of $0.5 \mathrm{~g}$ dry fruit sample. Phosphorus concentration was determined colorimetrically according to the method described by Murphy and Riley (1962). Potassium and sodium were determined by using flame photometer. Calcium and magnesium were determined by using the Versenate method (Cheng and Bray, 1957). Iron, manganese, zinc and copper concentrations were determined by using atomic absorption spectrophotometer (Perkin Elmer).

\section{Evaluation of semi-dry date palm seedlings:}

The present evaluation adopted the system of numerical evaluation of the tested semi-dry date palm seedling trees according to Abo-Rekabet al.(2012). The evaluation of any tested date palm seedling was calculated on the basis of 100 units. The hundred units were shared between the average yield per palm (20 units) as well as the fruit quality characteristics were distributed as follows: total sugar (20 units), tannins (10 units), flesh weight (20 units), TSS (15 units), total acidity ( 5 units) and crude fibers (10 units). To calculate the numerical units of evaluation for yield, flesh weight, as well as total sugar and total soluble solids percentage, it was proposed that maximum units for any of the for mentioned characters would be given to the date palm tree which had the highest value of such character under study. The other tested date palm trees would be given comparable units according to the following formulation:

Maximum units for character (x) X Recorded value for character $\left(\mathbf{x}^{\prime}\right)$ of any tested date palm tree Highest value for character $(\mathbf{X})$ On the other hand, for calculation of numerical units for tannins, total acidity and crude fibers percentages, it was proposed that maximum units for any of the previous characters would be given to the date palm tree which had the lowest value of such character under study. The other tested date palm trees would be given comparable units according to the following formula:

Maximum units for specific character $(x) X$ lowest value for character $\left(x^{\prime}\right)$

Recorded value for character (X) of any tested date palm tree RAPD-PCR analysis:

a. DNA extraction

Young and freshly excised tissue were collected separately for each tree. Then DNA extraction was performed as described by Dellaporta et al. (1983).

\section{b.Polymerase chain reaction $(\mathbf{P C R})$}

In order to obtain clear reproducible amplification products, different preliminary experiments were carried out in which a number of factors were optimized. These factors included PCR temperature cycle profile and concentration of each of 
the template DNA primer, $\mathrm{MgCl}_{2}$ and Taq polymerase. A total of twenty one random DNA oligonucleotide primers were independently used according to Williams et al. (1990) in the PCR reaction. Only five primers succeeded to generate reproducible polymorphic DNA products (Table 1).

Table 1. List of the primer names and their nucleotide sequences used in the study

\begin{tabular}{lcc}
\hline No. & Name & Sequence \\
\hline 1 & OP-C04 & 5 CCGCATCTAC3 \\
2 & OP-E19 & 5 ACGGCGTACG3 \\
3 & OP-G05 & 5 CTGAGACGGA3 \\
4 & OP-L20 & 5 TGGTGGACCA3` \\
5 & OP-Q15 & 5 TGCGATGCGA3 \\
\hline
\end{tabular}

\section{Statistical analysis:}

The experimental design was randomized complete block standard methods according to Snedecor and Cochran (1980). The new LSD test was used for the comparison between means.

The DNAbands generated by each primer were counted and their molecular sizes were compared with those of the DNA markers. The bands scored from DNA profiles generated by each primer were pooled together. Then the presence or absence of each DNA band was treated as a binary character in a data matrix (coded 1 and 0 , respectively) to calculate genetic similarity and to construct dendrogram tree among the studied seven semi-dry date palm trees. Calculation was achieved using Dice similarity coefficients (Dice, 1945) as implemented in the computer program SPSS-10.

\section{RESULTS AND DISCUSSION}

Panel taste (sensory evaluation):

The panel taste of the selected date palm seedling fruits was calculated on the basis of 35 units according to Abo-Rekab (2005). The results in Table (2) revealed that fruits of palm No. (6) recorded the full degrees $(35$ units) for fruit mouth feel, flavor, appearance acceptability and color. On the other hand, fruits of Seewy cultivar recorded the lowest degrees of units (32.88 units). Accordingly, from the sensory evaluation (Panel taste) it could be noticed that all selected semidry fruits of date palm had the quality of an excellent degree (>94\%), while the fruits of Seewy cultivar had the quality of a very good $(93.52 \%)$. Also, results revealed that the selected semi-dry fruits of date palm seedlings recorded a significant superiority over control (Seewy cultivar).

Table 2. Panel taste values of six semi-dry fruits of selected date palm seedlings and Seewy cultivar

\begin{tabular}{|c|c|c|c|c|c|c|c|c|c|c|c|c|c|c|}
\hline \multirow{2}{*}{$\begin{array}{l}\text { Seedlings } \\
\text { Seasons } \\
\text { (S) }\end{array}$} & \multicolumn{2}{|c|}{$\begin{array}{l}\text { Mouth feel } \\
\quad(10)\end{array}$} & \multicolumn{2}{|c|}{$\begin{array}{l}\text { Flavor } \\
(10)\end{array}$} & \multicolumn{2}{|c|}{$\begin{array}{c}\text { Appearance } \\
\text { acceptability } \\
\text { (10) }\end{array}$} & \multicolumn{2}{|c|}{$\begin{array}{l}\text { Color } \\
(5)\end{array}$} & \multicolumn{2}{|c|}{$\begin{array}{c}\text { Total degrees } \\
\text { (35) }\end{array}$} & \multicolumn{2}{|c|}{ Degrees (\%) } & \multicolumn{2}{|c|}{$\begin{array}{c}\text { Degrees of panel } \\
\text { taste }(\%)\end{array}$} \\
\hline & S1 & $\mathbf{S 2}$ & S1 & $\mathbf{S 2}$ & S1 & $\mathbf{S 2}$ & S1 & $\mathbf{S 2}$ & S1 & $\mathbf{S 2}$ & S1 & S2 & $\begin{array}{c}\text { Excellent } \\
(>94 \%)\end{array}$ & $\begin{array}{l}\text { V.good } \\
(\mathbf{9 0 - 9 4 \% )}\end{array}$ \\
\hline $\mathrm{T} 1$ & 9.17 & 9.30 & 9.88 & 9.94 & 9.37 & 9.41 & 4.95 & 4.92 & 33.37 & 33.57 & 95.34 & 95.91 & 95.63 & \\
\hline $\mathrm{T} 2$ & 9.96 & 9.96 & 9.51 & 9.7 & 9.97 & 9.98 & 4.94 & 4.96 & 34.38 & 34.62 & 98.23 & 98.91 & 98.57 & \\
\hline T3 & 9.38 & 9.43 & 9.83 & 9.87 & 9.76 & 9.79 & 4.80 & 4.87 & 33.77 & 33.96 & 96.49 & 97.03 & 96.76 & \\
\hline $\mathrm{T} 4$ & 9.93 & 9.95 & 9.91 & 9.91 & 9.95 & 9.95 & 4.98 & 4.98 & 34.77 & 34.79 & 99.34 & 99.46 & 99.37 & \\
\hline T5 & 9.47 & 9.52 & 9.52 & 9.58 & 9.30 & 9.35 & 4.69 & 4.73 & 32.98 & 33.18 & 94.23 & 94.80 & 94.52 & \\
\hline T6 & 10.00 & 10.00 & 10.00 & 10.00 & 10.00 & 10.00 & 5.00 & 5.00 & 35.00 & 35.00 & 100.00 & 100.00 & 100.00 & \\
\hline Seewy & 9.17 & 9.23 & 9.58 & 9.68 & 9.27 & 9.30 & 4.56 & 4.67 & 32.58 & 32.88 & 93.09 & 93.94 & & 93.52 \\
\hline New LSD & 0.23 & 0.21 & 0.09 & 0.06 & 0.10 & 0.09 & 0.08 & 0.06 & & & & & & \\
\hline
\end{tabular}

S1: Season 1 S2: Season 2

Vegetative characteristics of selected seedling date palm trees:

The results in Table (3) included the age, trunk height, trunk girth, number of leaves per palm, number of new leaves and leaf characteristics (leaf length, leaflets zone length, number of leaflets per leaf, leaflet

length, spine zone length, number of spines per leaf, spines length, leaf base length and leaf base width).

Results in Table (3) indicated that the ages of the selected semi-dry seedling date palm trees were varied as shown in Table (3). The average ages were about 10 years old.

Table 3.Vegetative characteristics of trees, number of leaves, annual new leaves and leaf morphological characters of selected semi-dry date palm seedlings as well as Seewy cultivar

\begin{tabular}{|c|c|c|c|c|c|c|c|c|c|c|c|c|c|c|c|c|c|c|c|c|c|c|c|c|c|c|c|c|}
\hline \multirow{2}{*}{ 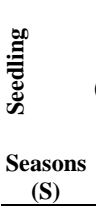 } & \multicolumn{2}{|c|}{$\begin{array}{c}\text { Age } \\
\text { (years) }\end{array}$} & \multicolumn{2}{|c|}{$\begin{array}{c}\text { Trunk } \\
\text { height (m) }\end{array}$} & \multicolumn{2}{|c|}{$\begin{array}{c}\text { Trunk } \\
\text { girth (m) }\end{array}$} & \multicolumn{2}{|c|}{$\begin{array}{c}\text { No. of } \\
\text { leaves/ } \\
\text { palm }\end{array}$} & \multicolumn{2}{|c|}{$\begin{array}{l}\text { No. of } \\
\text { new } \\
\text { leaves/ } \\
\text { palm }\end{array}$} & \multicolumn{2}{|c|}{$\begin{array}{l}\text { Leaf } \\
\text { length } \\
(\mathrm{m})\end{array}$} & \multicolumn{2}{|c|}{$\begin{array}{l}\text { Leaflets } \\
\text { zone } \\
\text { length } \\
\text { (m) }\end{array}$} & \multicolumn{2}{|c|}{$\begin{array}{l}\text { No. of } \\
\text { leaflets/ } \\
\text { leaf }\end{array}$} & \multicolumn{2}{|c|}{$\begin{array}{c}\text { Leaflet } \\
\text { length }(\mathrm{cm})\end{array}$} & \multicolumn{2}{|c|}{$\begin{array}{l}\text { Spine } \\
\text { zone } \\
\text { length } \\
(\mathrm{cm})\end{array}$} & \multicolumn{2}{|c|}{$\begin{array}{l}\text { No. of } \\
\text { spines/ } \\
\text { leaf }\end{array}$} & \multicolumn{2}{|c|}{$\begin{array}{c}\text { Spines } \\
\text { length } \\
(\mathrm{cm})\end{array}$} & \multicolumn{2}{|c|}{$\begin{array}{c}\text { Leaf base } \\
\text { length } \\
(\mathrm{cm})\end{array}$} & \multicolumn{2}{|c|}{$\begin{array}{c}\text { Leaf } \\
\text { base } \\
\text { width } \\
(\mathbf{c m})\end{array}$} \\
\hline & S1 & S2 & S1 & S2 & S1 & $\mathbf{S 2}$ & S1 & S2 & S1 & S2 & S1 & S2 & S1 & S2 & S1 & S2 & S1 & S2 & S1 & S2 & s1 & S2 & S1 & S2 & S1 & S2 & S1 & S2 \\
\hline $\mathrm{T} 1$ & 10 & 11 & 10.9 & 11.20 & 1.10 & 1.18 & 50 & 59 & 19 & 22 & 3.68 & 3.70 & 2.94 & 2.94 & 164.00 & 177.33 & 42.33 & 42.30 & 40.87 & 41.87 & 32.00 & 33.002 & 20.702 & 21.13 & 41.10 & 41.83 & 20.332 & 21.30 \\
\hline $\mathrm{T} 2$ & 10 & 11 & 11.5 & 11.70 & 1.50 & 1.63 & 69 & 76 & 21 & 24 & 3.41 & 3.41 & 2.86 & 2.85 & 153.33 & 166.00 & 49.33 & 50.10 & 58.48 & 59.60 & 27.33 & 29.00 & & 18.47 & 44.00 & 44.9 & 18.871 & 19.07 \\
\hline T3 & 10 & 111 & 10.58 & 10.78 & 1.75 & 1.86 & 57 & 64 & 20 & 25 & 3.05 & 3.21 & 2.34 & 2.50 & 145.33 & 151.33 & 38.83 & 39.17 & 34.17 & 35.33 & 18.33 & 20.00 & 15.231 & 15.97 & 48.33 & 48.97 & 17.031 & 17.77 \\
\hline $\mathrm{T} 4$ & 10 & 11 & 8.95 & 9.30 & 1.10 & 1.15 & 70 & 77 & 23 & 28 & 4.14 & 4.23 & 3.36 & 3.45 & 173.33 & 180.00 & 42.47 & 43.40 & 51.10 & 53.27 & 22.67 & 24.00 & 11.971 & 12.67 & 33.47 & 34.80 & 19.401 & 19.77 \\
\hline $\mathrm{T} 5$ & 10 & 11 & 12.0 & 12.25 & 1.83 & 1.93 & 52 & 60 & 18 & 23 & 4.18 & 4.27 & 3.57 & 3.58 & 182.00 & 191.33 & 46.80 & 47.60 & 80.80 & 82.03 & 29.00 & 31.332 & 21.972 & 23.10 & 21. & 22.03 & 14.331 & 14.93 \\
\hline T6 & 10 & 11 & 9.8 & 10.10 & 1.711 & 1.84 & 81 & 90 & 25 & 27 & 4.01 & 4.16 & 3.38 & 3.44 & 192.672 & 202.00 & 52.53 & 52.93 & 53.53 & 54.87 & 34.67 & 36.67 & 19.672 & 20.90 & 49.80 & 51.00 & 12.531 & 13.53 \\
\hline Seewy & 10 & 11 & 5.3 & 5.79 & 2.202 & 2.30 & 53 & 59 & 17 & 19 & 3.07 & 3.18 & 2.21 & 2.22 & 205.332 & 213.33 & 19.43 & 19.63 & 101.13 & 102.87 & 28.00 & 25.67 & 10.471 & 10.90 & 27.73 & 27.97 & 20.902 & 21.67 \\
\hline $\begin{array}{l}\text { New } \\
\text { LSD }\end{array}$ & & & & & & & & & & & 0.09 & 0.10 & 0.07 & 0.09 & 3.54 & 3.68 & 2.13 & 2.41 & 1.28 & 1.09 & 3.43 & 3.35 & 0.89 & 0.63 & 0.74 & 0.68 & 0.47 & 0.34 \\
\hline
\end{tabular}


The trunk height and girth of the selected semidry date palm seedlings as well as Seewy cultivar are shown in Table (3). Trunk height was positively related with age of the tree, while trunk girth was cultivar dependent.

The number of leaves/ tree for the selected semidry date palm seedlings as well as for Seewy cultivar in both seasons are shown in Table (3). In all the studied date palm trees, the average number of leaves were generally ranged from 50 to 90 leaves. On the other hand, the average number of annual newly leaves for semi-dry selected date palm seedlings as well as Seewy cultivar wereranged from 18 to 28 leaves per tree (Table 3 ). However, no obvious trend could be noticed to relate between date palm age and annual newly leaves or number of leaves per tree. These results are in agreement with those obtained from Abdalla (1979), Mousa (1981) and Abo-Rekab (2005).

Data of leaf morphological characters for selected semi-dry date palm seedlings as well as for Seewy cultivar are presented in Table (3). In both seasons, the average lengths of leaf, leaflets zone, leaflet, spines zone, spine and leaf base of selected semi-dry date palm seedlings were ranged from 3.05 to $4.27 \mathrm{~m}, 2.34$ to $3.58 \mathrm{~m}, 38.83$ to $53.53 \mathrm{~cm}, 34.17$ to $82.03 \mathrm{~cm}, 11.97$ to $23.10 \mathrm{~cm}$ and 21.43 to $51.00 \mathrm{~cm}$, respectively. In addition, the average numbers of leaflets and spines/ leaf for semi-dry selected date palm seedlings were ranged from 145.33 to 202.00 and 18.33 to 36.67 , respectively in both seasons. The average width of leaf base for the selected semi-dry seedling date palm were ranged in both seasons from 12.53 to $21.30 \mathrm{~cm}$. it appears that most of the morphological leaf characters for the studied selected semi-dry seedlings and age were genotype dependent. In addition, it was noticed that all the leaf morphological characters values for the semi-dry selected date palm seedlings were significantly higher as compared with those for Seewy cultivar values.

Time dates of flowering, fruit set and harvesting as well as fruit yield and its components:

The time dates of spathe emergence and opening, fruit set, harvesting date, number and weight of bunches, and yield for the selected semi-dry date palm seedlings as well as Seewy cultivar are shown in Table (4).

Table 4. Date of flowering, fruit set, harvesting date, number, weight of bunches and yield for selected semidry date palm seedlings

\begin{tabular}{|c|c|c|c|c|c|c|c|}
\hline $\begin{array}{l}\text { Character } \\
\text { Seedling }\end{array}$ & $\begin{array}{c}\text { Spathe } \\
\text { emergence }\end{array}$ & Spathe opening & Fruit set & Harvesting date & $\begin{array}{l}\text { No. of bunch/ } \\
\text { palm }\end{array}$ & $\begin{array}{c}\text { Bunch weight } \\
\text { (kg) }\end{array}$ & $\begin{array}{c}\text { Yield/ palm } \\
\text { (kg) }\end{array}$ \\
\hline \multicolumn{8}{|l|}{ Season 2014} \\
\hline $\mathrm{T} 1$ & $18^{\text {th }}$ March & $26^{\text {th }}$ March & $2^{\text {nd }}$ April & $17^{\text {th }}$ Oct. & 12.0 & 10.0 & 120.0 \\
\hline $\mathrm{T} 2$ & $17^{\text {th }}$ March & $25^{\text {th }}$ March & $3^{\text {rd }}$ April & $8^{\text {th }}$ Oct. & 14.0 & 9.0 & 126.0 \\
\hline $\mathrm{T} 3$ & $20^{\text {th }}$ March & $28^{\text {th }}$ March & $5^{\text {th }}$ April & $10^{\text {th }}$ Sept. & 11.0 & 10.0 & 110.0 \\
\hline $\mathrm{T} 4$ & $21^{\text {st }}$ March & $29^{\text {th }}$ March & $6^{\text {th }}$ April & $13^{\text {th }}$ Sept. & 13.0 & 9.5 & 123.5 \\
\hline T5 & $23^{\text {rd }}$ March & $31^{\text {st }}$ March & $10^{\text {th }}$ April & $16^{\text {th }}$ Oct. & 11.0 & 10.1 & 111.1 \\
\hline T6 & $16^{\text {th }}$ March & $24^{\text {th }}$ March & $2^{\text {nd }}$ April & $12^{\text {th }}$ Oct. & 15.0 & 10.0 & 150.0 \\
\hline Seewy & $12^{\text {th }}$ March & $20^{\text {th }}$ March & $30^{\text {th }}$ March & $23^{\text {rd }}$ Sept. & 10.0 & 10.4 & 104.0 \\
\hline $\begin{array}{l}\text { Character } \\
\text { Seedling }\end{array}$ & $\begin{array}{c}\text { Spathe } \\
\text { emergence }\end{array}$ & Spathe opening & Fruit set & Harvesting date & $\begin{array}{l}\text { No. of bunch/ } \\
\text { palm }\end{array}$ & $\begin{array}{c}\text { Bunch weight } \\
\text { (kg) }\end{array}$ & $\begin{array}{c}\text { Yield/ palm } \\
\text { (kg) }\end{array}$ \\
\hline \multicolumn{8}{|l|}{ Season 2015} \\
\hline $\mathrm{T} 1$ & $19^{\text {th }}$ March & $28^{\text {th }}$ March & $4^{\text {th }}$ April & $18^{\text {th }}$ Oct. & 13.0 & 9.7 & 126.1 \\
\hline $\mathrm{T} 2$ & $18^{\text {th }}$ March & $27^{\text {th }}$ March & $8^{\text {th }}$ April & $11^{\text {th }}$ Oct. & 14.0 & 9.0 & 126.0 \\
\hline $\mathrm{T} 3$ & $21^{\text {st }}$ March & $29^{\text {th }}$ March & $7^{\text {th }}$ April & $12^{\text {th }}$ Sept. & 12.0 & 10.0 & 120.0 \\
\hline $\mathrm{T} 4$ & $22^{\text {nd }}$ March & $31^{\text {st }}$ March & $9^{\text {th }}$ April & $15^{\text {th }}$ Sept. & 14.0 & 9.3 & 130.2 \\
\hline T5 & $25^{\text {th }}$ March & $1^{\text {st }}$ April & $12^{\text {th }}$ April & $19^{\text {th }}$ Oct. & 12.0 & 9.9 & 118.8 \\
\hline T6 & $17^{\text {th }}$ March & $26^{\text {th }}$ March & $6^{\text {th }}$ April & $14^{\text {th }}$ Oct. & 16.0 & 10.0 & 160.0 \\
\hline Seewy & $13^{\text {th }}$ March & $21^{\text {st }}$ March & $1^{\text {st }}$ April & $25^{\text {th }}$ Sept. & 11.0 & 10.5 & 115.5 \\
\hline
\end{tabular}

In all the studied semi-dry date palm seedlings, the average dates of spathes emergence and opening were generally ranged from $16^{\text {th }}$ March to $25^{\text {th }}$ March and $24^{\text {th }}$ March to $1^{\text {st }}$ April, respectively. Meanwhile, the average dates for fruit set were ranged from $2^{\text {nd }}$ April to $12^{\text {th }}$ April. Similar results were obtained with Brown andBahgat (1938), Mougheithet al. (1976), Abo-Rekab (2005 and 2013).s

The dates of harvesting for semi-dry date palm seedlings as well as Seewy cultivar are presented in Table (4). In both seasons, the average date for harvesting of selected semi-dry date palm seedlings were ranged from $8^{\text {th }}$ October to $19^{\text {th }}$ October and $23^{\text {rd }}$ September to $25^{\text {th }}$ September, respectively. Data presented in Table (4) indicated that the average number of bunches/ tree as well as the average bunch weight for semi-dry date palm seedlings as well as Seewy cultivar in both seasons were ranged from 10.0 to $16.0 \mathrm{bunch} /$ tree and 9.0 to $10.5 \mathrm{~kg}$, respectively. The average fruit yield/ tree reached about 110.0 to $160.0 \mathrm{~kg}$. number of bunches, bunch weight and fruit yield of semi-dry date palm seedlings showed higher values comparing with those obtained from Seewycultivar. These results are in agreement with the findings of Mougheithet al. (1976), Abo-Rekab (2005 and 2013) and Abo-Rekabet al. (2014).

Fruit physical characteristics:

Data of fruit and flesh weight of semi-dry date palm seedlings as well as Seewy cultivar were presented in Table (5) and Fig. (1). In both seasons, the average fruit and flesh weight of semi-dry date palm seedlings were ranged from 16.59 to $24.23 \mathrm{~g}$ and 14.70 to $22.38 \mathrm{~g}$, respectively. It was noticed that all the semi-dry date palm seedlings were significantly higher as compared with those for Seewy cultivar.

The fruit physical characters, i.e. length, diameter and seed weight of semi-dry date palm seedlings as well as Seewy cultivar were presented in Table (5).

Data of Table (5) showed that fruit length, diameter and seed weight were ranged from 3.63 to $7.55 \mathrm{~cm}, 2.31$ to $3.42 \mathrm{~cm}$ and 1.65 to $2.18 \mathrm{~g}$, respectively in both seasons. It was noticed that these results are in agreement with those findings of Mougheithet al.(1976), Abo-Rekab (2005 and 2013) and Abo-Rekabet al. (2014). 
Table .5. fruit physical characterstics for the selected semi-dry date palm seeding as well as seewy cultivar

\begin{tabular}{|c|c|c|c|c|c|c|c|c|c|c|}
\hline \multirow{2}{*}{$\begin{array}{l}\text { Character } \\
\text { Seedling }\end{array}$} & \multicolumn{2}{|c|}{$\begin{array}{c}\text { Fruit weight } \\
\text { (g) }\end{array}$} & \multicolumn{2}{|c|}{$\begin{array}{c}\text { Flesh weight } \\
\text { (g) }\end{array}$} & \multicolumn{2}{|c|}{ Fruit length $(\mathrm{cm})$} & \multicolumn{2}{|c|}{ Fruit diameter $(\mathbf{c m})$} & \multicolumn{2}{|c|}{ Seed weight (g) } \\
\hline & S1 & S2 & S1 & S2 & S1 & S2 & S1 & S2 & S1 & S2 \\
\hline $\mathrm{T} 1$ & 18.61 & 18.70 & 16.79 & 16.87 & 7.53 & 7.55 & 2.58 & 2.61 & 1.81 & 1.83 \\
\hline $\mathrm{T} 2$ & 17.59 & 17.86 & 15.67 & 15.91 & 3.63 & 3.73 & 2.51 & 2.54 & 1.91 & 1.95 \\
\hline $\mathrm{T} 3$ & 19.57 & 20.43 & 17.41 & 18.25 & 5.97 & 6.07 & 3.13 & 3.25 & 2.16 & 2.18 \\
\hline $\mathrm{T} 4$ & 16.59 & 17.13 & 14.70 & 15.24 & 6.42 & 6.53 & 2.31 & 2.36 & 1.88 & 1.90 \\
\hline T5 & 24.03 & 24.27 & 22.38 & 22.58 & 4.97 & 5.10 & 3.35 & 3.42 & 1.65 & 1.69 \\
\hline T6 & 23.80 & 23.93 & 21.77 & 21.82 & 6.83 & 6.89 & 3.03 & 3.13 & 2.03 & 2.12 \\
\hline Seewy & 15.81 & 15.94 & 13.93 & 14.05 & 3.97 & 4.07 & 2.81 & 2.84 & 1.58 & 1.61 \\
\hline New LSD & 0.22 & 0.18 & 0.26 & 0.16 & 0.10 & 0.07 & 0.07 & 0.04 & 0.06 & 0.04 \\
\hline
\end{tabular}

Chemical constituents of semi-dry date palm fruits:

Chemical constituents of fruits i.e, moisture, dry matter, total soluble solids, ash, crude fibers, total sugar, total acidity, tannins, soluble phenols, total soluble indoles, crude protein and total soluble free amino acids concentrations for the selected semi-dry date palm seedlings as well as Seewy cultivar are presented in Table (6). In both seasons, the moisture and dry matter percentages of the semi-dry date palm seedlings fruits were ranged from 20.83 to $28.73 \%$ and 70.37 to $79.17 \%$, respectively. On the other hand, the total soluble solids and ash percentages of semi-dry date palm seedling tree No. 6 recorded higher significant values (55.63 and 3.03\%, respectively) as compared with the other tested seedlings andSeewy cultivar. On the other hand, the crude fibers percentage of semi-dry date palm seedling no. 6 recorded the higher degree for quality (minimum percentage of crude fibers) as compared to the other tested seedlings or Seewy cultivar.
Data in Table (6) revealed that semi-dry date palm seedling No. 6 was characterized by significant higher values of total sugar percentage comparing with those values obtained from the other studied seedlings or Seewy cultivar. On the other hand, the fruits of semi-dry seedling No. 6 contained the lowest percentage of acidity as compared to other tested date palm seedlings or Seewy cultivar. The lowest values of tannins, soluble phenols and total soluble indoles concentrations (low levelwas indicator for best fruit quality) were recorded by date palm seedling No. 4. In general, soluble phenols concentration in date palm fruits was gradually decreased till the maturity. Such decrease might be attributed to the conversion of soluble to insoluble tannins during maturation or to decrease in metabolic activity to synthesize shikimic acid in such plants (Maier and Metzler, 1962), Abo-Rekab (2005 and 2013).

Table (6): Chemical constituents of selected semi-dry date palm seedlings fruits as well as Sewwy cultivar.

\begin{tabular}{|c|c|c|c|c|c|c|c|c|c|c|c|c|}
\hline Character & $\begin{array}{c}\text { Moisture } \\
(\%)\end{array}$ & $\begin{array}{c}\text { Dry matter } \\
(\%)\end{array}$ & $\begin{array}{l}\text { TSS } \\
(\%)\end{array}$ & $\begin{array}{l}\text { Ash } \\
(\%)\end{array}$ & $\begin{array}{l}\text { Crude } \\
\text { fibers } \\
(\%)\end{array}$ & $\begin{array}{c}\text { Total } \\
\text { sugars } \\
(\%)\end{array}$ & $\begin{array}{c}\text { Total } \\
\text { acidity } \\
(\%)\end{array}$ & $\begin{array}{c}\text { Tannins } \\
(\%)\end{array}$ & $\begin{array}{c}\text { Total } \\
\text { soluble } \\
\text { phenols } \\
\text { (mg/100gf. } \\
\text { wt.) }\end{array}$ & $\left.\begin{array}{c}\text { Total indoles } \\
(\mathrm{mg} / \mathbf{1 0 0 g}\end{array}\right)$ & $\begin{array}{l}\text { Crude } \\
\text { proteins } \\
(\%)\end{array}$ & $\begin{array}{c}\text { Total free } \\
\text { amino acids } \\
(\mathrm{mg} / 100 \mathrm{gW})\end{array}$ \\
\hline
\end{tabular}

$\begin{array}{lllllllllllllllllllllllll}\frac{\text { Seasons (S) }}{\text { Trees }} & \text { S1 } & \text { S2 } & \text { S1 } & \text { S2 } & \text { S1 } & \text { S2 } & \text { S1 } & \text { S2 } & \text { S1 } & \text { S2 } & \text { S1 } & \text { S2 } & \text { S1 } & \text { S2 } & \text { S1 } & \text { S2 } & \text { S1 } & \text { S2 } & \text { S1 } & \text { S2 } & \text { S1 } & \text { S2 } & \text { S1 } & \text { S2 }\end{array}$

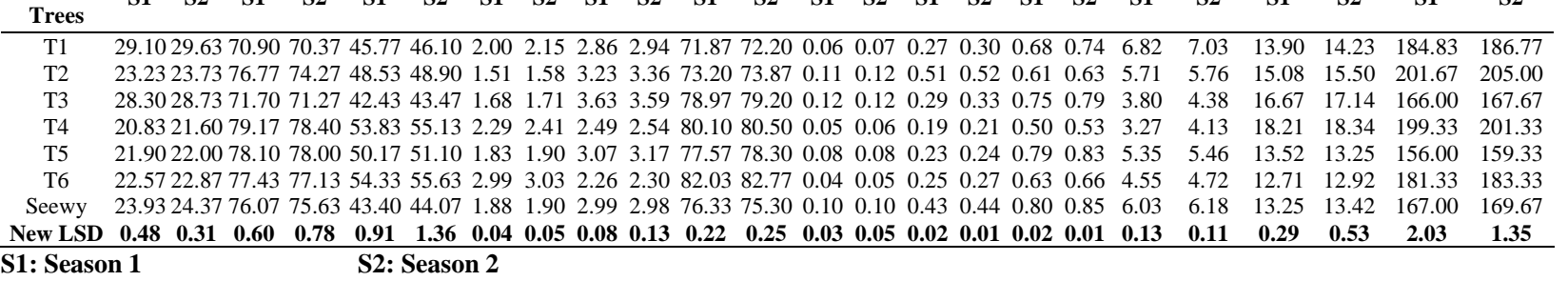

Crude protein and total free amino acids concentrations in fruits of semi-dry date palm seedlings as well as Seewy cultivar are presented in Table (6). Data revealed that fruits of semi-dry date palm seedling No. 4 were characterized bythe higher significant concentrations of crude protein and total free amino acids as compared to both compounds in fruits of the other tested date palm seedlings or Seewy cultivar. In general, elevated protein concentrations in fruits at maturity in trees might reflect the effectivity of such trees to synthesize and translocate the assimilated compounds to fruits. In this regard, Liu et al. (2001) mentioned that there were some parallel relationships among hormones, enzymes and protein accumulation. The action of hormones could be achieved through their influence on enzymes activities.

Nowadays the use of nutritional content is one way to develop for crop selection, mainly when we observe good correlation between the production and the nutrients content (Furlaniet al. 2001). Generally, the nutritional value and quality of fruits are depending upon genotype and growing conditions.

The macro-nutrients, i.e. nitrogen, phosphorus, potassium, calcium and magnesium concentrations in fruits of selected semi-dry date palm seedlings as well as Seewy cultivar are presented in Table (7). Data revealed that $\mathrm{N}, \mathrm{Mg}$ and $\mathrm{Ca}$ concentrations recorded significant highest in fruits of seedling date palm No. 4 comparing with Seewy cultivar. Fruits of semi-dry date palm tree No. 1containing significant higher concentrations of $\mathrm{P}$ and $\mathrm{K}$ comparing with Seewy cultivar. Semi-dry seedling No. 2 recorded the highest significant concentration of $\mathrm{Na}$ comparing with Seewy cultivar.

In this concern, Volzet al. (2001) stated that calcium content of fruits was found to be a heritable trait, suggesting that selection and breeding for high-Ca cultivars is possibility for improving post-harvest quality. They added that $\mathrm{Ca}$ seems to be acting as stabilizer of cell wall and cell membranes in fruits. 
Of course, increasing the micro-nutrients content of date palm fruits increase their quality. The micronutrients, i.e. $\mathrm{Mn}, \mathrm{Fe}, \mathrm{Zn}$ and $\mathrm{Cu}$ concentrations in fruits of selected semi-dry date palm seedlings as well as Seewy cultivar were presented in Table (7). Data indicated that fruits of seedling No. 5 contained the highest significant concentration of $\mathrm{Mn}$, while seedling No. 2 contained the highest significant concentration of Fe. The highest significant concentration of $\mathrm{Zn}$ was recorded by seedling No. 1. Meanwhile, the highest concentration of $\mathrm{Cu}$ was recorded by fruits of Seewy cultivar. These results are in agreement with those obtained from Abo-Rekab (2005) and Abo-Rekab and El-Kerdany (2009).

\section{General evaluation:}

The general evaluation of the semi-dry date palm seedlings as well as Seewy cultivar (control) are summarized in Table (8). The semi-dry date palm No. 6 ranks the first for its productivity and fruit quality as it attained the maximum accumulative units (96.38 units) as compared to the other semi-dry seedling palms. Palm No. 4 ranks the second as it attained 89.88 units. The third rank was gained by the semi-dry date palm seedling No. 5, it attained (83.52 units) followed by tree No. 1 which had the fourth rank and gave 78.71 units. The fifth rank was gained by seedling tree No. 3 which attained 78.71 units. The semi-dry seedling date palm No. 2 had the sixth rank, it obtained 70.89 units. Finally in the seventh and last rank came in the descending orderSeewy cultivar, it gained 70.43 units. In general, there were six semi-dry date palm seedlings arranged in descending order tree No. 6, No. 4, No. 5, No. 1 , No. 3 and No. 2 in their superiority in their yield and fruit qualities than Seewy cultivar.
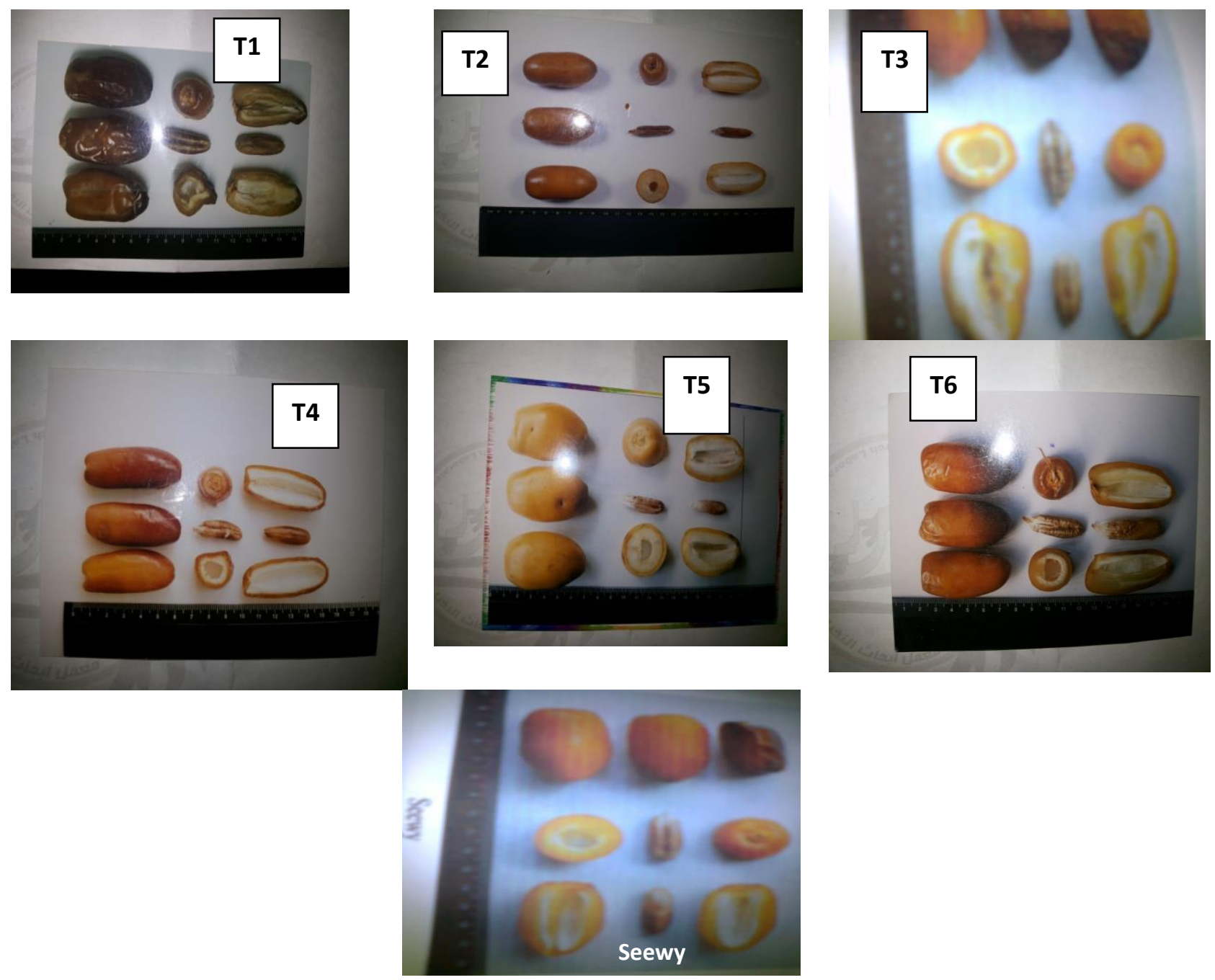

Fig.1. Fruit characters of the six semi-dry date palm seedlings $\left(T_{1}-T_{6}\right)$ vs. the Seewy cultivar

Identification of different selected semi-dry seedlings date palm as well as Seewy cultivar by utilizing RAPD:

To determine the genetic relationships among the 6 maghal seedlings semi-dry date palm as well as Seewy cultivar, RAPD-profile resulting from using 5 tested primers, i.e. OP-C04, OP-E19, OP-G05, OP-L20 and OP-Q15 were illustrated in Table (1) and Fig. (2).
The results of RAPD-PCR using OP-C04 showed amplification products of DNA bands with molecular size ranged from 2200 to $180 \mathrm{bp}$. Seven bands were found to be monomorphic, whereas five bands were polymorphic. The RAPD pattern using primr OP-E19 indicated the amplification of six bands with molecular size ranged from 920 to $280 \mathrm{bp}$. Two bands were found to be monomorphic. The RAPD patterns driven by 
primer OP-G05 showed amplification products eleven bands with molecular size ranged from 1800 to $275 \mathrm{bp}$. from which six bands were polymorphic, whereas the five bands were monomorphic. The results of primer OP-L20 indicated the amplification of nine bands with molecular size ranged from 880 to $270 \mathrm{bp}$, eight of them were polymorphic and the other band was cultivar specific marker at $880 \mathrm{bp}$. The one specific DNA band was absent for semi-dry seedling tree No. 4 (negative marker). The last primer OP-Q15 indicated that amplification of seven bands with a molecular size ranged from 1300 to $170 \mathrm{bp}$.were obtained. Seven of them were monomorphic, whereas the other bands (seven bands) were polymorphic in which one of them was cultivar specific marker at $230 \mathrm{bp}$. One specific DNA band with a molecular size $230 \mathrm{bp}$. was absent for seedling tree No. 2. In general, the total number of amplified DNA fragments was 52 bands by using the five-10 mer random primers, 29 bands among them were polymorphic (Table 9). Two RAPD-PCR cultivarspecific negative marker were detected with primer OPL20 and OP-Q15. Meanwhile, the two primers OP-C04 and OP-E19 did not show any specific DNA cultivar marker. Several reports came out in which RAPD genetic relationships among them (Schnell et al. 1995, Litz, 1997, Abo-Rekabet al. 2010 and Abo-Rekabet al. 2012). Because of their abundance in the genome, stability, and their high level of polymorphism, DNA marker such as RAPDs have greatest utility than protein markers (Abo-Rekab et al. 2010 and Abo-Rekabet al. 2012).

Table 7. Mineral nutrients (macro and micro nutrients concentrations) in fruits of selected semi-dry date palm seedlings as well as Seewy cultivar.

\begin{tabular}{llllllllccc}
\hline Mineral & $\mathrm{N}(\%)$ & $\mathrm{P}(\%)$ & $\mathrm{K}(\%)$ & $\mathrm{Ca}(\%)$ & $\mathrm{Mg}(\%)$ & $\mathrm{Na}(\%)$ & $\begin{array}{c}\mathrm{Mn} \\
(\mathrm{mg} / \mathrm{g} \mathrm{DW})\end{array}$ & $\begin{array}{c}\mathrm{Fe} \\
(\mathrm{mg} / \mathrm{g} \mathrm{DW})\end{array}$ & $\begin{array}{c}\mathrm{Zn} \\
(\mathrm{mg} / \mathrm{g} \mathrm{DW})\end{array}$ & $\begin{array}{c}\mathrm{Cu} \\
(\mathrm{mg} / \mathrm{g} \mathrm{DW})\end{array}$ \\
Seasons & & & & & & &
\end{tabular}

$\begin{array}{lllllllllllllllllllll}(\mathbf{S}) & \text { S1 } & \text { S2 } & \text { S1 } & \text { S2 } & \text { S1 } & \text { S2 } & \text { S1 } & \text { S2 } & \text { S1 } & \text { S2 } & \text { S1 } & \text { S2 } & \text { S1 } & \text { S2 } & \text { S1 } & \text { S2 } & \text { S1 } & \text { S2 } & \text { S1 } & \text { S2 }\end{array}$ Tree

\begin{tabular}{llllllllllllllllllllll}
\hline T1 & 2.22 & 2.28 & 2.04 & 2.09 & 3.04 & 3.18 & 1.21 & 1.25 & 2.21 & 2.31 & 1.96 & 2.01 & 38.33 & 39.67 & 212.67 & 218.33 & 64.67 & 67.33 & 9.27 & 9.53
\end{tabular}

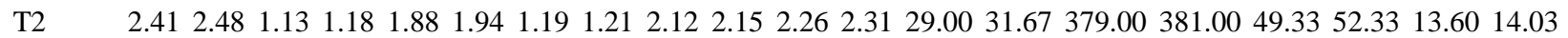

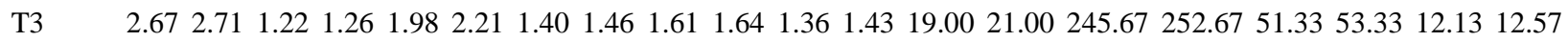

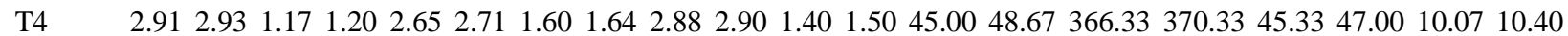

$\begin{array}{lllllllllllllllllllll}\text { T5 } & 2.16 & 2.19 & 1.82 & 1.89 & 2.57 & 2.61 & 1.32 & 1.42 & 2.43 & 2.52 & 1.29 & 1.34 & 54.33 & 57.00 & 224.67 & 231.33 & 41.00 & 42.00 & 15.03 & 15.33\end{array}$

$\begin{array}{lllllllllllllllllllll}\text { T6 } & 2.03 & 2.07 & 1.62 & 1.68 & 2.94 & 2.99 & 1.29 & 1.31 & 2.48 & 2.55 & 1.42 & 1.52 & 50.67 & 54.00 & 241.33 & 244.67 & 47.00 & 50.00 & 13.03 & 13.40\end{array}$

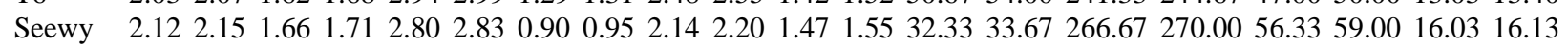

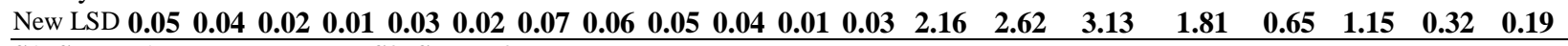

S1: Season 1 S2: Season 2

Table 8. General evaluation of selected semi-dry date palm seedlings as well as Seewy cultivar grown in Fayoum governorate during 2013 and 2014.

\begin{tabular}{lccccccccc}
\hline Index & $\begin{array}{c}\text { Yield/ } \\
\text { palm } \\
\text { (kg) }\end{array}$ & $\begin{array}{c}\text { Flesh } \\
\text { weight } \\
\text { (g) }\end{array}$ & $\begin{array}{c}\text { Total } \\
\text { sugars } \\
\mathbf{\%}\end{array}$ & $\begin{array}{c}\text { T.S.S } \\
\mathbf{\%}\end{array}$ & $\begin{array}{c}\text { Total } \\
\text { acidity } \\
\mathbf{\%}\end{array}$ & $\begin{array}{c}\text { Tannins } \\
\text { (g/100g) }\end{array}$ & $\begin{array}{c}\text { Crude } \\
\text { fibers } \\
\mathbf{\%}\end{array}$ & $\begin{array}{c}\text { Color } \\
\text { General } \\
\text { evaluation }\end{array}$ \\
$\begin{array}{l}\text { units } \\
\text { Seedling }\end{array}$ & $\mathbf{2 0}$ & $\mathbf{1 0}$ & $\mathbf{2 0}$ & $\mathbf{1 0}$ & $\mathbf{1 0}$ & $\mathbf{1 5}$ & $\mathbf{1 0}$ & $\mathbf{5}$ & $\mathbf{1 0 0}$ \\
\hline T1 & 15.76 & 7.47 & 17.45 & 8.29 & 6.62 & 10.60 & 7.90 & 4.62 & 78.71 \\
T2 & 15.75 & 7.05 & 17.85 & 8.74 & 3.77 & 5.78 & 6.99 & 4.95 & 70.89 \\
T3 & 15.00 & 8.08 & 19.14 & 7.81 & 3.61 & 10.09 & 6.23 & 4.84 & 74.75 \\
T4 & 16.28 & 6.75 & 19.45 & 9.91 & 8.43 & 15.00 & 9.08 & 4.98 & 89.88 \\
T5 & 14.85 & 10.00 & 18.92 & 9.20 & 5.73 & 12.75 & 7.36 & 4.71 & 83.52 \\
T6 & 20.00 & 9.66 & 20.00 & 10.00 & 10.00 & 11.72 & 10.00 & 5.00 & 96.38 \\
Seewy & 14.44 & 6.22 & 18.19 & 7.92 & 4.39 & 6.78 & 7.56 & 4.93 & 70.43 \\
\hline
\end{tabular}

The polygenetic relationships among the studied semi-dry date palm trees utilizing RAPDs markers:

The dendrogramtree and the similarity indices among the six-semi-dry seedlings and Seewy cultivar utilizing RAPD-PCR markers presented in Table (10) and Figure (3) using dice computer package. The strongest relationship was scored between seedling No. 1 and No. 4 as well as between tree No. 6 and Seewy cultivar (similarity of $100 \%$ ). The dendrogram tree based on DNA analysis was divided into two clusters. The first contains only seedling tree No. 1 . The second cluster was divided into two subclusters. The first subcluster contains seedling No. 6. The second subcluster was divided into two groups. The first group contains Seewy cultivar, while the second group was divided into two subgroups. The first subgroup contains tree No. 3. The second subgroup was divided into two subgroups. The first subgroup contains tree No. 5, while the second subgroup contains tree No. 2 and tree No. 4. 


\section{RAPD -PCR}
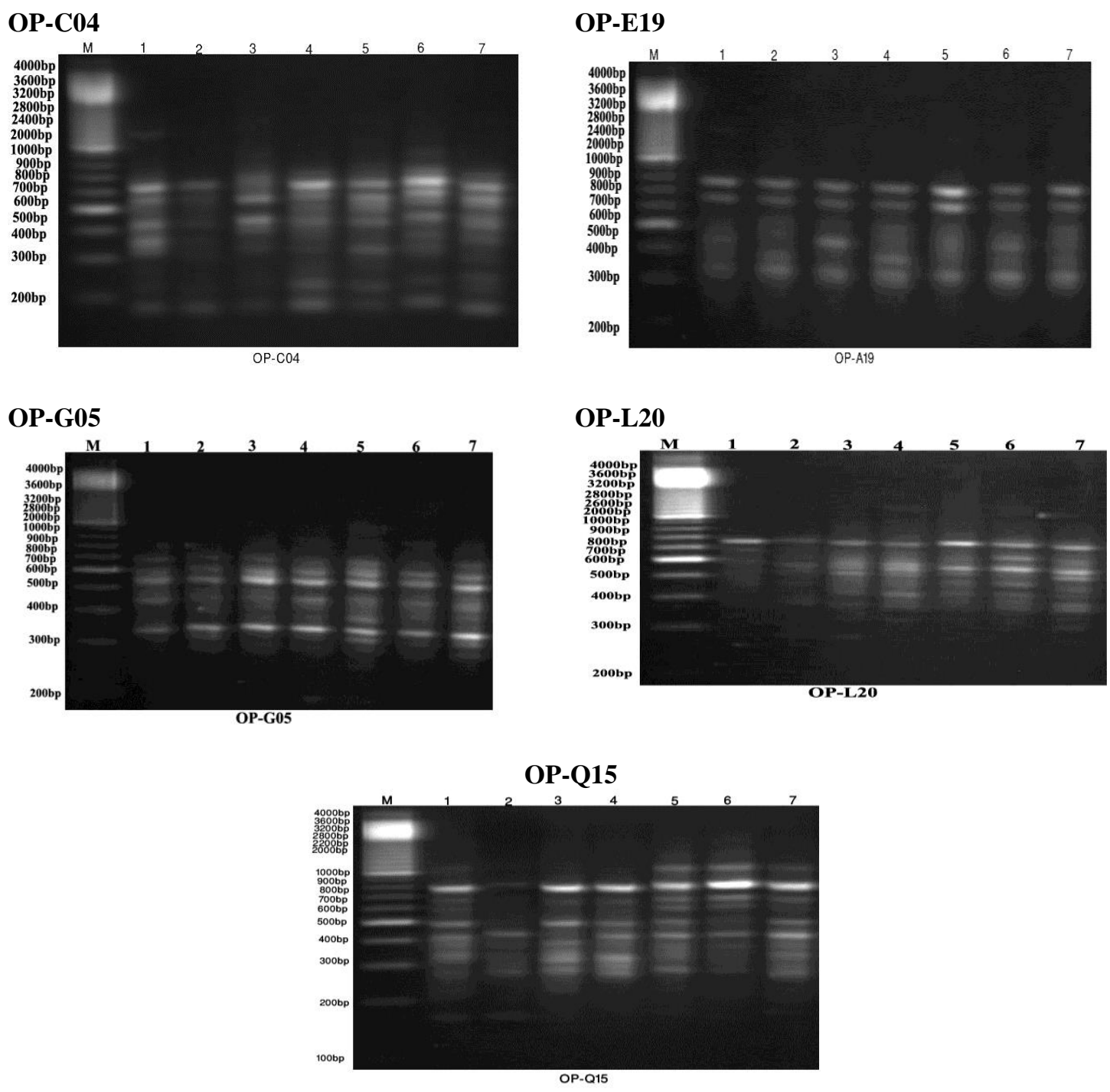

Fig. 2. RAPD-DNA products generated with primers OP-C04, OP-E19, OP-G05, OP-L20 and OP-Q15 in six selected semi-dry date palm seedlings as well as Seewy cultivar

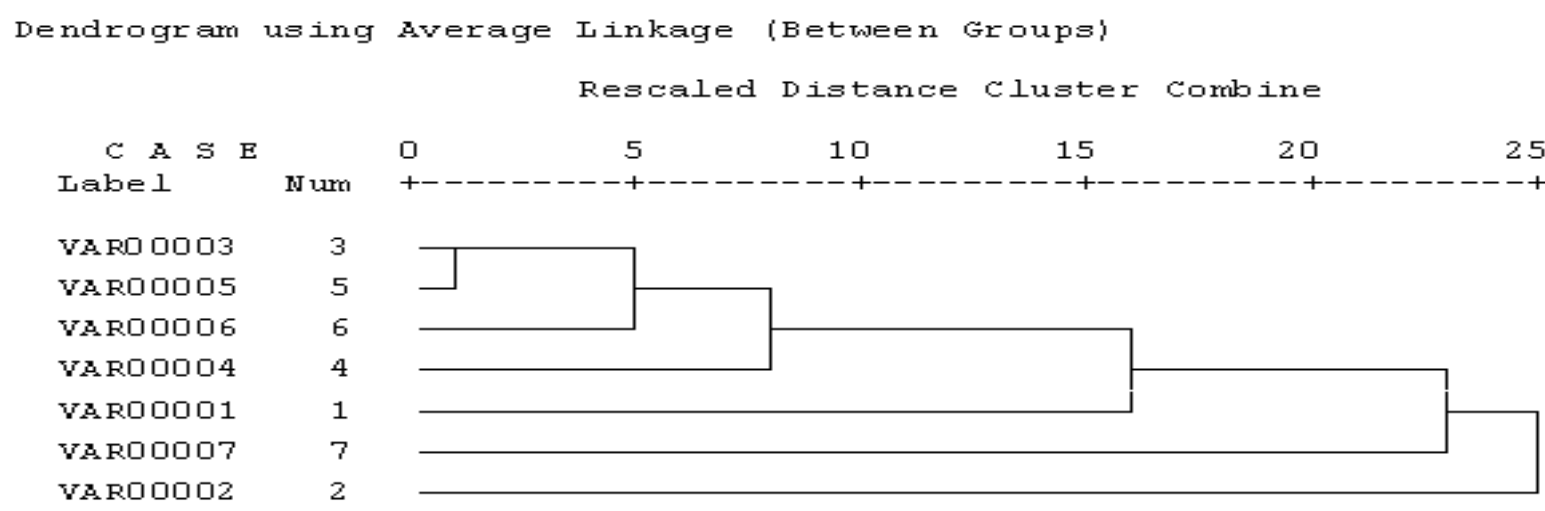

Fig. (3): Dendrogramfor the six selected semi-dry date palm seedlings as well as Seewy cultivar accessions constructed from RAPD-DNA data using unweighed pair-group arithmetic (UPGMA) and similarity matrices computed according to Dice coefficient. 
Table 9. Genetic similarity matrices among the six selected semi-dry date palm seedling trees as well as Seewy cultivar accessions as computed according to dice coefficient from RAPD-DNA

\begin{tabular}{|c|c|c|c|c|c|}
\hline $\begin{array}{l}\text { Primer } \\
\text { Name }\end{array}$ & $\begin{array}{c}\text { Amplifie } \\
\text { d Band }\end{array}$ & $\begin{array}{l}\text { Polymorphic } \\
\text { Band }\end{array}$ & $\begin{array}{l}\text { MonoMorphic } \\
\text { Band }\end{array}$ & $\begin{array}{c}\text { Unique } \\
\text { Band }\end{array}$ & $\begin{array}{c}\text { Polymorphic } \\
\%\end{array}$ \\
\hline $\begin{array}{l}\mathrm{OP}- \\
\mathrm{C} 04\end{array}$ & 12 & 5 & 7 & - & 41.67 \\
\hline $\begin{array}{l}\text { OP- } \\
\text { E19 }\end{array}$ & 6 & 2 & 4 & - & 33.33 \\
\hline $\begin{array}{l}\text { OP- } \\
\text { G05 }\end{array}$ & 11 & 6 & 5 & - & 54.55 \\
\hline $\begin{array}{l}\text { OP- } \\
\text { L20 }\end{array}$ & 9 & 8 & - & $1-$ & 88.88 \\
\hline $\begin{array}{l}\text { OP- } \\
\text { Q15 }\end{array}$ & 14 & 7 & 7 & $1-$ & 50.00 \\
\hline Total & 52 & 29 & 23 & 2 & 56.8 \\
\hline
\end{tabular}

Table 10. Genetic similarity matrices among the six selected semi-dry seedlings as well as Seewy cultivar accessions as computed according to Dice coefficient from RAPD-DNA

\begin{tabular}{lllllll}
\hline & Seewy & $\mathbf{1}$ & $\mathbf{2}$ & $\mathbf{3}$ & $\mathbf{4}$ & $\mathbf{5}$ \\
\hline Seewy & & & & & & \\
$\mathbf{1}$ & 0.7 & & & & & \\
$\mathbf{2}$ & 0.7 & 0.7 & & & & \\
$\mathbf{3}$ & 0.3 & .05 & 0.1 & & & \\
$\mathbf{4}$ & 0.4 & 1.0 & 0.0 & 0.1 & & \\
$\mathbf{5}$ & 0.3 & 0.7 & 0.2 & 0.3 & 0.0 & \\
$\mathbf{6}$ & 1.0 & 0.9 & 0.6 & 0.7 & 0.7 & 0.4 \\
\hline
\end{tabular}

\section{REFERENCES}

Abdalla, M. Y. (1979). Studies on soft date cultivars.M.Sc. thesis.Faculty of Agriculture, Zagazig University, Egypt.

Abo-Rekab, Zeinab A.M. (2005): Some physiological studies on date palm. Ph.D. thesis.Faculty of Agriculture, Cairo University, Egypt.

Abo-Rekab, Zeinab A. M. (2013). The genetic diversity analysis of some Egyptian oasis seedling date palm fruits and its physical characteristics and chemical composition. J. Biol. Chem. Environ. Sci., 8(3): 433-450.

Abo-Rekab, Z.A.M. and El-Kerdany, A.Y. (2009). Evaluation of Seewy date palm cultivar irrigated by both treated waste water and Nile Water. $4^{\text {th }}$ Conference on Recent Technologies in Agriculture.

Abo-Rekab, Z.A.M.; El-Kafrawy, T.M. and Ghada A.A. (2014).Selection of good male date palm pollinators for improving both yields and fruit quality using morphological characterization and genetic relationships of pollinators using ISSR markers.Scientific J. Flowers \& Ornamental Plants.www.ssfup.com. Journal ISSN: 23567864.

Abo-Rekab, Zeinab A. M.; Gadalla, E.G. and Mohamed, S.Y. (2010).Morphological, physiological and molecular genetic evaluation of the most important Egyptian dry date palm. J. Biol. Chem. Environ. Sci., 5(3): 23-47.
Abo-Rekab, Zeinab A. M.; Tahany Y. Saber and Mohamed, A.M. (2012). Selection of high quality fruits of some dry date palm seedling trees and their identification as well as Sakkoty cultivar utilizing (RAPD DNA) technique. J. Biol. Chem. Environ. Sci., 7(3): 323-347.

AOAC (1980).Methods of Analysis $13^{\text {th }}$ ed. Association of Official Agriculture Chemists, Washington.D.C. U.S.A.

AOAC (1985).Methods of Analysis $19^{\text {th }}$ ed. Association of Official Agriculture Chemists, Washington.D.C. U.S.A.

Brown, T.W. and Bahgat, M. (1938).Date Palm in Egypt.Booklet No. 24, Horticulture Section, Ministry of Agriculture, Egypt.

Cheng, K.L. and Bray, R.H. (1957).Determination of Calcium and Magnesium in soil and plant materials. Soil Sci., 72: 449-458.

Chen, P.M. and Mellenthin, W.M. (1981).Effect of harvest date on ripening capacity and postharvest life of d'Anjouears. J. Amer. Soc. Hort. Sci., 106 (1): 38-42.

Dawson, V. H. W. and Aten, A. (1963).Dates handling, processing and packing F.A.O. Agricultural Development. Paper No. 72, Food and Agriculture Organization of the United Nations, Rome.

Dellaporta, S.L.; Wood, J. and Hicks, J.B. (1983).A plant DNA minipreparation version II. Plant Molecular Biology Reporter 1, No.4, 19-21.

Dice, L. R. (1945).Measures of the amount of ecologic association between species. Ecology, 26: 297-302.

Dubois, M.; Gilles, K. A.;Hamitton, J. K.;Rebers, P. A. and Smith, F. (1956).Colorimetric methods for determination of sugars and related substances.Anal. Chem. 28: 350-356.

El-Warraki, A. G.; Oweda, E. G. and Youssef, M. (1989). Studies on Al Madinah Al Monawara dates 1. Some physical and quality characteristics. Ann. Agric. Sci. Fac. 34(1): 519-643.

Furlani, R. C. M.; Furlani Jr. E.; Moreira, R. C. and Moreas, M. L. T. (2001). Genetic variation in rubber tree progenies: Macronutrients contents. Plant nutrition.Food security and sustainability of agro ecosystems through basic and applied research. Kluwer Academic Publishers, Dororecht, Boston, London. PP. 94-95.

Larson, P.; Harbo, A.; Klungsour, S. and Aasheim, T. (1962).AcetobacterXylinum. Physiol. Plant. 15: 552-65.

Litz, R. E. (1997). The mango, botany, production and uses. $1^{\text {st }}$ ed. CAB International, New York, USA, PP. 587. 
Liu, X.; Jin, J.; Yang, S. and Wang, G. (2001).Physiological aspects of wheat genotypes differing in protein content.Plant nutrition food security and sustainability of agro-ecosystems through basic and applied research.Klumer Academic Publishers, Dordrecht, Boston, London. PP. 344-345.

Maier, V. P. and Metzler, D. M. (1962).Phenolic constituents of the date and their relation to browning congr. $1^{\text {st }}$ International Congress Food Science Technology, pp.21-24.

Mougheith, M. G.; Hassaballa, I. A. and El-Ashrum, M. A. (1976). Comparative studies on fruit development quality and bunch characteristics at harvest of some Egyptian date cultivars. Anal. Agric. Sci., Moshtohor, 5: 179-193.

Mousa, I.A. (1981). Evaluation and studies of some seedling date palms grown at Ismailia Province. M.Sc. Thesis. Faculty of Agriculture, Zagazig University, Egypt.

Murphy, J. and Riley, J. P. (1962).A modified single solution method for the determination of phosphorus in natural water.Anal. Chem. Acta, 27: 31-36.

Nixon, R. W. and Carpenter, J. B. (1978). Growing dates in United States. U.S. Dept. of Agric., Information Bulletin No. 207: USDA. Technical Document 63 pp.

Pregl. F. (1945).Quantitative Inorganic Microanalysis.4th ed. J. Grant, p. 78. London: Churchill.

Resenabatt, M. and Peluso, J. V. (1941).Determination of tannins by spectrophotometer. J. Asso. Offic.Agr. Chemists, 24: 170.

Rokba, A. M.; Seif, S. A. and Abou El-Azayem, A. I. (1990).Biological studies on some date palm seedling grown in Fayoum governorate. J. Agric., Sci., Mansoura Univ., 15(2): 232-238.
Rosin, H. (1957).A modified ninhydrine colorimetric analysis for amino acids.Biochem.Biophys., 67: 10-5.

Schnell, R. J. Ronning, C. M. and Knight, R. J. (1995).Identification of cultivars and variation of genetic relationships in MangiferaIndica L. using RAPD markers. Theoretical and applied genetics, 90: 269-274.

Sedra, M.H.;Filali, H.E.L and Frira, D.(1993).Observarions on some agronomic and phenotypic characteristics of the fruit varieties and selected clones of date palm. AlAwamia, 82:105-120.

Sedra, M.H.; Lashermes,P.; Trouslot, P.; Combes, M.C.;et al. (1998).Identification and genetic diversity analysis of date palm (Phoenix dactylifera L.) varieties of Morocco using RAPD markers. Euphytica103:75-82.

Snedecor, G. W. and Chorcan, W. G. (1980).Statistical Methods. $7^{\text {th }}$ ed., the Iowa state univ. press. Ames., Iowa, USA. PP. 593.

Swain, T. and Hillis, W. E. (1959).The phenolic constituents of Prunus domestica-1- The quantitative analysis of phenolic constituents. J. Sci. Food Agri., 10: 63-68.

Volz, R. K.; Alspach, P. A.; White, A. G. and Ferguson, I. B. (2001).Genetic variability in mineral accumulation of apple fruit nutrition food security and sustainability of agroecosystems through basic and applied research.Kluwer Academic Publishers, Dororecht, Boston, London. PP. 92-93.

Williams, J. G. K.; Kubelik , A. R.; Livak, K. J.;Rafalski , J. A. and Tingey, S. V. (1990). DNA polymorphisms amplified by arbitrary primers are useful as genetic markers. Nucleic Acids Res., 18: 6531-6535.

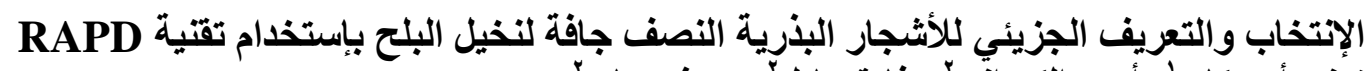

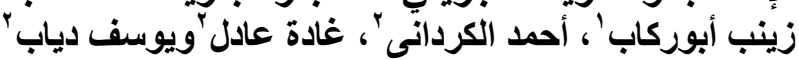
قسم تربية الفاكهة ونباتات الزينة - معهد بحوث البساتين، المعمل المركزى لأبحاث وتطوير النخيل ـ مركز البحوث الزراعية

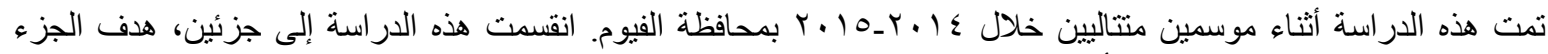

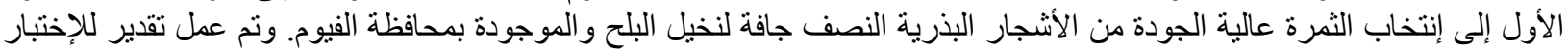

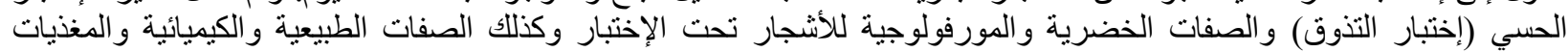

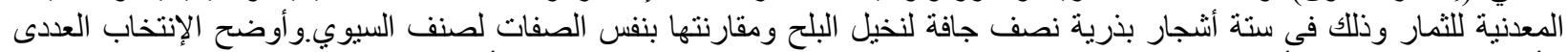

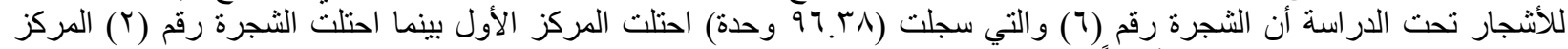

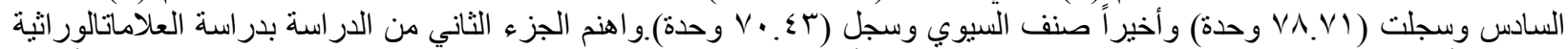

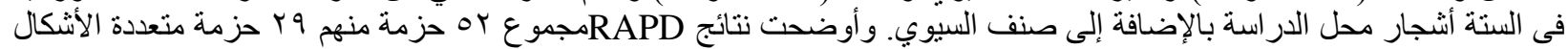

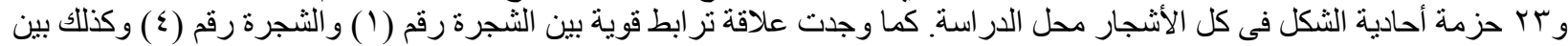

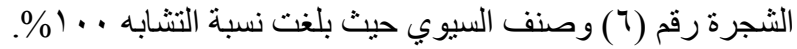

